\title{
Essential trichomegaly: case report
}

\section{Tricomegalia essencial: relato de caso}

Julia Dutra Rossetto ${ }^{1}$, Heloisa Nascimento ${ }^{1}$, Cristina Muccioli², Rubens Belfort JR. ${ }^{2}$

\section{ABSTRACT}

The present study reports two cases of symptomatic essential trichomegaly. Trichomegaly may develop in various diseases, including anorexia nervosa, hypothyroidism, pregnancy, pretibial myxedema, systemic lupus erythematosus, vernal keratoconjunctivitis, and uveitis. The exact incidence trichomegaly is unknown, and the condition remains sporadically reported. Two cases of symptomatic trichomegaly without any associated systemic disorder are presented in this paper.

Keywords: Visual acuity/etiology; Hypertrichosis/complications; Eyelashes/pathology; Case reports

\section{RESUMO}

O presente estudo tem por objetivo relatar dois casos de tricomegalia essencial com diminuição da acuidade visual. A tricomegalia pode se desenvolver em várias doenças, incluindo anorexia nervosa, hipotireoidismo, gravidez, mixedema pré-tibial, lúpus eritematoso sistêmico, ceratoconjuntivite primaveril, e uveíte. A incidência da tricomegalia essencial é desconhecida e a condição permanece esporadicamente relatada. São apresentados dois casos de tricomegalia sintomática em pacientes sem distúrbios sistêmicos associados.

Descritores: Acuidade visual/etiologia; Hipertricose/complicações; Pestanas/patologia; Relatos de casos

\section{INTRODUCTION}

The periocular hair holds special significance given its central location. Eyelash dysfunction may have significant effects, ranging from ocular discomfort to visual acuity decrease. The hair's unique importance and location often results in early detection of pathology ${ }^{(1)}$. Beyond vanity, periocular hair disease may indicate a wide spectrum of systemic or localized pathology. Trichomegaly or hypertrichosis is defined as an increase in the length, thickness, stiffness, curling, and pigmentation of existing eyelashes beyond normal variation for a patient's ethnicity, age, and/or gender ${ }^{(2)}$.

Usually trichomegaly is an isolated finding, although it can be encountered in the context of generalized acquired hypertrichosis or secondary to irritation or inflammation.

The purpose of this paper is to present two cases of patients with symptomatic essential trichomegaly.

\section{CASE REPORT}

Patient 1. A 63 year-old male patient with medical history of treated prostate cancer five years ago and considered cured and with an unremarkable past ocular history. His complaint was decreased visual acuity in both eyes. The ophthalmological exam disclosed trichomegaly, as seen below (Figure 1).
Patient 2. A 72 year-old female patient with medical history of diabetes, systemic hypertension and hypercholesterolemia and with an unremarkable past ocular history. Her complaints comprised decrease of visual acuity and burning sensation. Ocular exam revealed hypertrichosis in both eyes, as seen below (Figure 2).

Both patients were seen at the Department of Ophthalmology of Escola Paulista de Medicina (Hospital São Paulo/UNIFESP) and the systemic and ophthalmologic work-up excluded infection as well as other diseases. Both denied use of systemic medication.

Both patients were submited to eyelash trimming with improvement of their visual quality.

\section{DISCUSSION}

Trichomegaly is a rare condition that may develop in various diseases, including anorexia nervosa, acrodynia, dermatomyositis, hypothyroidism, pregnancy, pretibial myxedema, porphyria, metastatic renal cell adenocarcinoma, systemic lupus erythematosus, vernal keratoconjunctivitis, and uveitis ${ }^{(3,4)}$, as well as linear scleroderma, hepatopathy ${ }^{(5,6)}$, and leishmania/Kala-azar ${ }^{(4,5,7)}$. Congenital conditions such as Oliver-McFarlane syndrome ${ }^{(8)}$, oculocutaneous albinism type $\left.\right|^{(9)}$, or familial hypertrichosis ${ }^{(10)}$ are also associated with hypertrichosis. AIDS is among the well-studied systemic causes of trichomegaly ${ }^{(1)}$, although primarily described during later disease stages.
Funding: No specific financial support was available for this study.

Disclosure of potential conflicts of interest: J.D.Rossetto, None; H.Nascimento, None; C.Muccioli, None; R.Belfort Jr, None.

Corresponding author: Júlia Rossetto. Rua Botucatu, 821 - São Paulo (SP) - 04023-062 - Brazil E-mail: Julia_rossetto@hotmail.com 


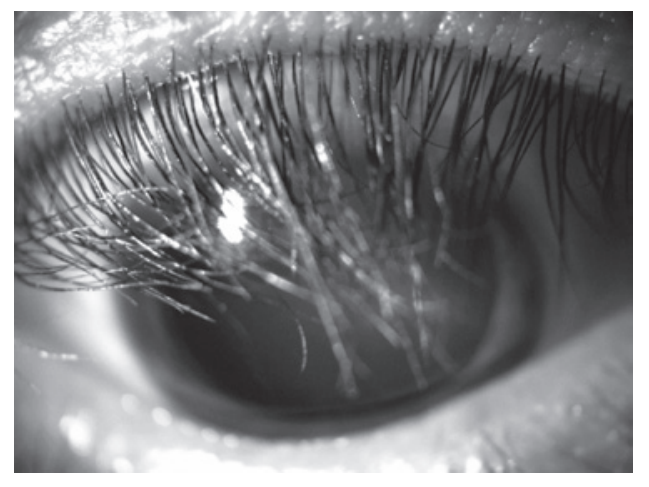

Figure 1. Trichomegaly on the right eye (Patient 1).

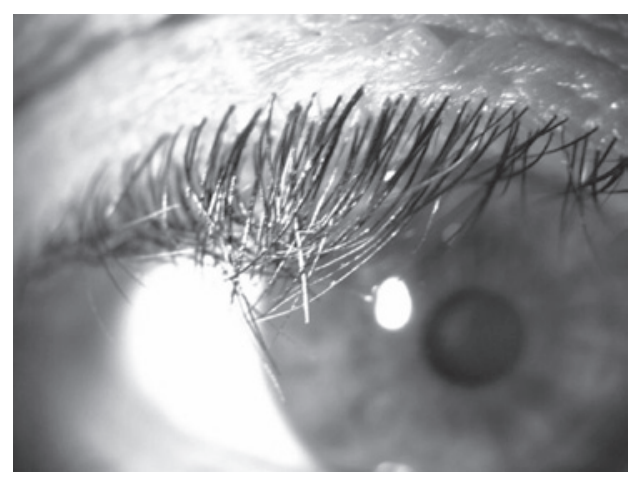

Figure 2. Trichomegaly on the right eye (Patient 2).
Nazareth et al.(11) documented 23 medications associated with trichomegaly. The most common were prostaglandin analogs, cyclosporine, interferon, topiramate and cetuximab.

\section{CONCLUSION}

Trimming and epilation have been found to be satisfactory and safe therapeutic options. The exact incidence of eyelash trichomegaly is unknown, and the condition is rare and sporadically reported.

\section{REFERENCES}

1. Modjtahedi BS, Alikhan A, Maibach HI, Schwab IR. Diseases of periocular hair. Surv Ophthalmol. 2011:56(5):416-32.

2. Braiteh F, Kurzrock R, Johnson FM. Trichomegaly of the eyelashes after lung cancer treatment with the epidermal growth factor receptor inhibitor erlotinib. J Clin Oncol. 2008;26(20):3460-2.

3. Wendelin DS, Pope DN, Mallory SB. Hypertrichosis. J Am Acad Dermatol. 2003;48(2): 161-79; quiz 180-1. Review.

4. Schneiderman PI, Grossman ME. A clinician's guide to dermatologic differential diagnosis. Boca Raton: Informa Healthcare; 2006.

5. Almagro M, del Pozo J, García-Silva J, Martínez W, Castro A, Fonseca E. Eyelash length in HIV-infected patients. AIDS. 2003;17(11):1695-6.

6. Kaplan MH, Sadick NS, Talmor M. Acquired trichomegaly of the eyelashes: a cutaneous marker of acquired immunodeficiency syndrome. J Am Acad Dermatol. 1991; 25(5 Pt 1):801-4. Comment in J Am Acad Dermatol. 1993;28(3):513.

7. Ward KM, Barnett C, Fox LP, Grossman ME. Eyelash trichomegaly associated with systemic tacrolimus. Arch Dermatol. 2006;142(2):248.

8. Oliver GL, McFarlane DC. Congenital trichomegaly: with associated pigmentary degeneration of the retina, dwarfism, and mental retardation. Arch Ophthalmol. 1965; 74:169-71.

9. Ziakas NG, Jogiya A, Michaelides M. A case of familial trichomegaly in association with oculocutaneous albinism type 1. Eye (Lond). 2004;18(8):863-4.

10. Harrison DA, Mullaney PB. Familial trichomegaly. Arch Ophthalmol. 1997;115(12):1602-3.

11. Nazareth MR, Bunimovich O, Rothman IL. Trichomegaly in a 3-year-old girl with alopecia areata. Pediatr Dermatol. 2009;26(2):188-93. 